\title{
Evaluation of activities of dipteran maggots on a poisoned pig cadaver at Nnamdi Azikiwe University Awka, Nigeria
}

\author{
Maduamaka Cyriacus Abajue ${ }^{1 *}$ (D) and Sylvanus Chima Ewuim²
}

\begin{abstract}
Background: Forensic entomology is evolving into entomotoxicology, which is a critical approach in forensic toxicology that alternatively assesses presence of toxins in insects that have eaten a decomposing cadaver. Toxic substances in or on a dead body may accumulate in the tissues of fly maggots while feeding on the body and thus may alter their developmental rate. Thus, four out of eight healthy pigs (Sus scrofa Linn.) that weighed on the average $22.3 \pm 1.9 \mathrm{~kg}$ were sacrificed with zinc phosphide as food poison, while the remaining four pigs were sacrificed by strangulation during the rainy and dry seasons of 2014 and 2015 respectively. Their bodies were deposited in a building to mimic indoor decomposition. The building is on $6^{\circ} 15^{\prime} 18.06^{\prime \prime} \mathrm{N}$ and $7^{\circ} 06^{\prime} 41.37^{\prime \prime} \mathrm{E}$ at Nnamdi Azikiwe University Awka, Anambra State, Nigeria. The effect of the zinc phosphide on the decomposition duration of the cadavers was monitored. Toxicological assessment of zinc and phosphorus on maggots found on the cadavers was performed with an atomic absorption spectrophotometer.

Findings: The zinc phosphide did not affect the decomposition duration of the cadaver and did not prolong or shortened the life cycle of the fly maggots when compared with the control (strangled pig cadaver). For the poisoned cadavers, the atomic absorption spectrophotometer detected zinc in the maggot tissues collected from them while phosphorus was not detected. Neither zinc nor phosphorus was detected in the maggot tissues collected from the strangled cadavers.

Conclusions: The study showed that the zinc component in the zinc phosphide commonly used as rodenticide in Awka can be detected in maggots collected from such a suspected poisoned cadaver. Other implications related to toxicological studies on cadaveric insects in forensic entomology and serving as alternative matrices in forensic toxicology in any questionable death were also highlighted.
\end{abstract}

Keywords: Zinc phosphide, Pig cadaver, Decomposition, Dipteran maggots, Forensic entomology

\section{Introduction}

Forensic entomology is the use of the biological knowledge of insects in a death investigation when a cadaver has decomposed and infested with insects. The use of insects in death investigation has been extended in crime scenes on land and water (Keiper and Casamatta 2001; Hobischak and Anderson 2002). It is also evolving into entomotoxicology,

\footnotetext{
* Correspondence: maduamaka.abajue@uniport.edu.ng

'Department of Animal and Environmental Biology, University of Port Harcourt, Port Harcourt, Nigeria

Full list of author information is available at the end of the article
}

which is a critical approach in forensic toxicology that alternatively assesses presence of toxins in insects that have eaten a decomposing cadaver. Apparently, the use of insects in crime scene investigation has been well documented (Smith 1986; Gennard 2007), and the history is revalidated (Benecke 2001; Greenberg and Kunich 2002).

Toxic substances in or on a dead body may accumulate in the tissues of fly maggots while feeding on the body and thus may alter their developmental rate. Insects especially fly maggots that feed on a cadaver may be suspected to retain undigested flesh from the corpse

\section{Springer Open}

(c) The Author(s). 2020 Open Access This article is licensed under a Creative Commons Attribution 4.0 International License, which permits use, sharing, adaptation, distribution and reproduction in any medium or format, as long as you give appropriate credit to the original author(s) and the source, provide a link to the Creative Commons licence, and indicate if changes were made. The images or other third party material in this article are included in the article's Creative Commons licence, unless indicated otherwise in a credit line to the material. If material is not included in the article's Creative Commons licence and your intended use is not permitted by statutory regulation or exceeds the permitted use, you will need to obtain permission directly from the copyright holder. To view a copy of this licence, visit http://creativecommons.org/licenses/by/4.0/. 
while they are still feeding on a cadaver. In some circumstances, the flesh from the corpse can retain some type of poison that had been consumed before the person died which may even be the cause of such questionable death. Studies have shown that poisons can be assessed on immature stages of insects that have fed on suspicious poisoned cadavers (Introna et al. 1990). Toxicological and DNA examinations on a body in a state of advanced decomposition or a skeletonized body may be difficult to examine. This is because relevant substances such as tissues, blood, or urine at this stage are lacking in such cadaver. Hence, immature insects collected from such body can alternatively serve as toxicological samples when the victim is suspected to die of a poisonrelated issue (Introna et al. 2001; Campobasso et al. 2004). Maceration of fly maggots that fed on poisoned cadavers prior to toxicological analysis with chromatography and other related machines has been submitted as alternative means of carrying out forensic toxicology instead of using cadaveric samples that may be lacking at the time of the examination (Goff and Lord 1994; Miller et al. 1994; Gagliano-Candela and Aventaggiato 2001; Bourel et al. 2001).
Apparently, determining the time and cause of a questionable death of a corpse is always difficult if the body is badly decomposed. But still, it is an important component of coronal death investigation. In this study therefore, the decomposition duration in days of poisoned and strangled pig cadavers as models to human corpse were studied in a building at Nnamdi Azikiwe University Awka, Anambra State, Nigeria. Fly maggot samples collected on the cadavers were assessed for zinc and phosphorus, and some samples were reared to determine the influence of the poison on the development of the fly maggots into adult flies.

\section{Materials and methods}

The study was carried out during the rainy and dry seasons of 2014 and 2015 respectively at Nnamdi Azikiwe University Awka, Nigeria. The site chosen for the study was the animal house in the Zoology garden of the University located on latitude $6^{\circ} 15^{\prime} 18.06^{\prime \prime} \mathrm{N}$ and longitude $7^{\circ} 06^{\prime} 41.37^{\prime \prime}$ E (Fig. 1). Awka as a town is located on latitudes $6^{\circ} 09^{1} \mathrm{~N}$ and $6^{\circ} 19^{1} \mathrm{~N}$ and longitudes $7^{\circ} 01^{1} \mathrm{E}$ and $7^{\circ} 12^{1} \mathrm{E}$ (Enete et al. 2014) and stretches $8 \mathrm{~km}$ in an east-west direction along the Enugu-Onitsha expressway

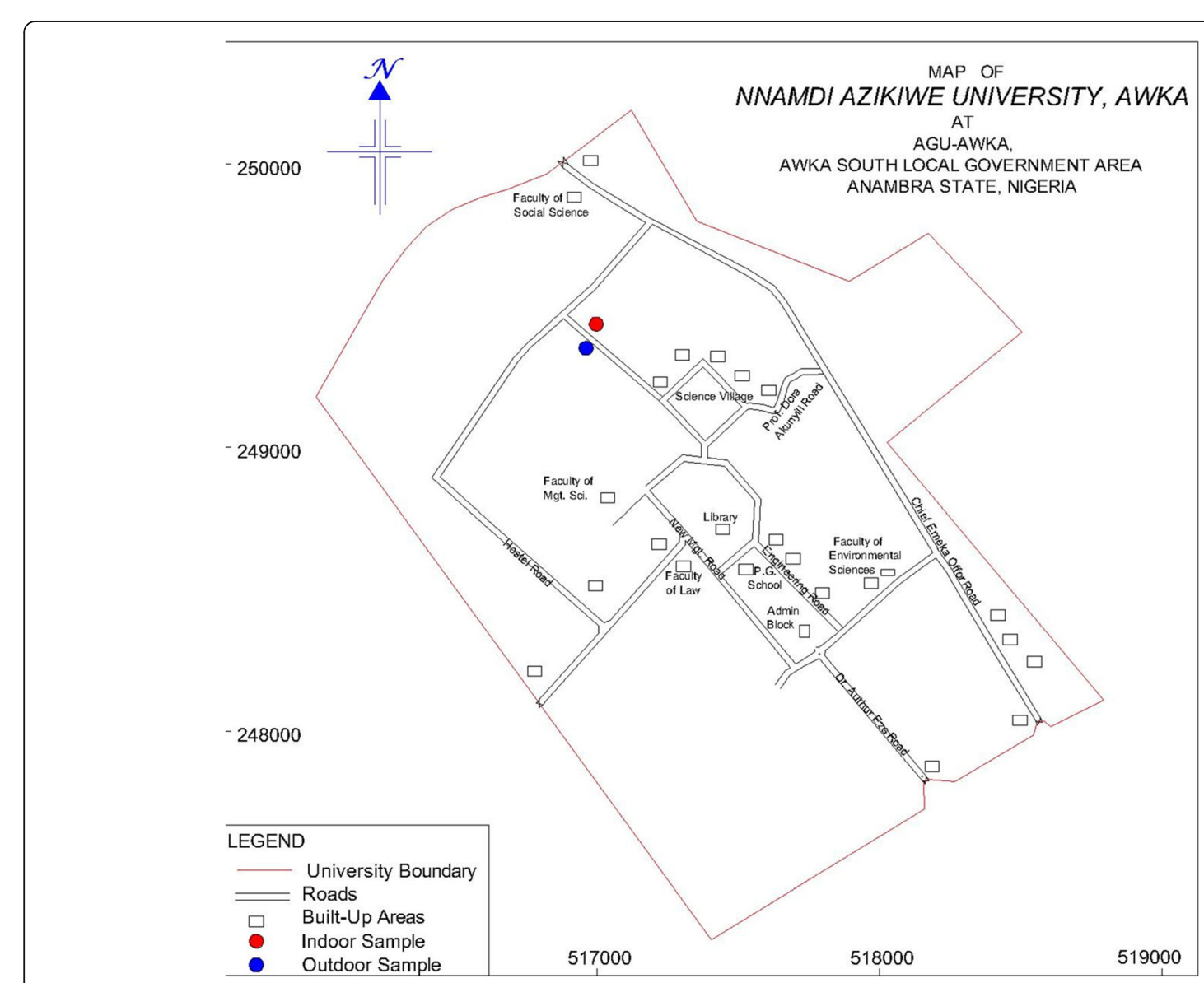

Fig. 1 Map of Nnamdi Azikiwe University Awka, Nigeria (red circular dot was the study location) 
and about $5 \mathrm{~km}$ in a north-south orientation. The dimension of Awka is $1,207,800 \mathrm{~m}^{2}$ or 12,007 ha. Ecologically, Awka lies in the Guinea Savanna and has experienced $1798.52 \mathrm{~mm}$ of rain annually between 1977 and 2012 (Enete et al. 2014). It experiences two seasons: the dry and the wet seasons with a spell of harmattan between December and January.

Eight healthy pigs, (Sus scrofa Linn.) with a mean weight of $22.3 \pm 1.9 \mathrm{~kg}$ purchased from a piggery, were used for the study (Fig. 2). Pig cadaver was chosen for the study as alternative for human model because of its analog to human cadaver and has been reported to attract similar arthropod fauna recorded for human cadavers in studies relating to forensic entomology (Tomberlin et al. 2012). Four pigs were sacrificed with zinc phosphide (poison). Zinc phosphide is the active ingredient in a rodenticide sold in open market at Awka, Nigeria, as rat poison with a trade name as "commandorat killer". It is a systemic poison that is used to mix different crumbs as rat baits. Occasionally, the poison has been alleged to be used to commit suicide because of its availability, accessibility, and affordability. Each of the pigs was fed with $10 \mathrm{~g}$ of the poison by admixture in $500 \mathrm{~g}$ of spent grains to mimic food poison and was later euthanized. The remaining four pigs were also euthanized prior to their strangulation each by tightening their necks with aluminum cable until death to mimic forced natural death. (Euthanasia was done by a licensed veterinary doctor.)

In the Zoology garden, a simulated building (i.e., a wooden hut measuring 24 - $\mathrm{ft}$ length, 20 - $\mathrm{ft}$ width, and 10$\mathrm{ft}$ height) roofed with a corrugated metal sheet was erected (Fig. 3). Thus, the building simulated a minimum room in Awka, Anambra State. The roof of the building overlapped with the erected woods with little crevices in between the roof and the woods; hence, no ceiling was provided after roofing. The ground of the building was floored with concrete cement. The building has one window measuring $10 \times 10 \mathrm{~cm}^{2}$ and an entrance door measuring $8-\mathrm{ft}$ high and $2-\mathrm{ft}$ wide. The window remained closed throughout the study period while the door was only opened for collection of dipteran maggots and remained closed while collection was on going. The building simultaneously housed two poisoned and two strangled pig cadavers deposited $3 \mathrm{~m}$ apart on sacks measuring $16 \times 8 \mathrm{~cm}^{2}$ that serve as deposition mats and insect collection limit. The pig cadavers were allowed to skeletonize during the rainy season. The same number of pigs and killing processes and the experiments were repeated during the dry season of the study in 2015 .

The relative humidity and the ambient temperature of the building were taken with digital thermo-hygrometer (Mextech TM-1, model). About 100 maggots at their third instar stages found on the poisoned and strangled pig cadavers were separately collected on day 4, day 6 , and day 8 and were labeled as first batch of the cadaveric maggots. On day 10 and day 12, another group of maggots that were distinctively different from the first batch of maggots were collected and labeled as the second batch of the cadaveric maggots. On day 14, day 16, day 18 , and day 20 , another group of maggots entirely different from the maggots of first and second batches were collected and labeled the third batch of the cadaveric maggots. These maggots were collected with $5 \mathrm{ml}$ spoon and blunt forceps. Adult flies found on the cadavers were collected with entomological sweep net. In each batch of the maggots collected from the poisoned and strangled pig cadavers, 20 maggots were collected from each of them specifically on day 4 for first batch, day 8 for second batch, and day 14 for third batch. These 20

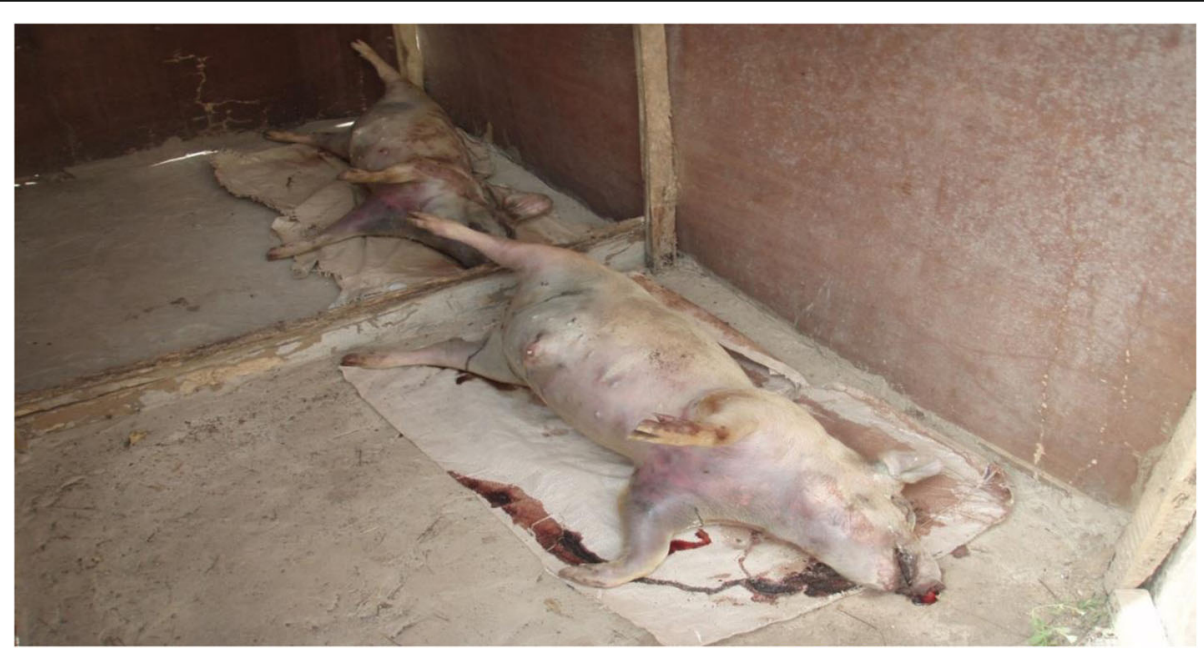

Fig. 2 Pig cadavers in the simulated building in Awka, Nigeria 


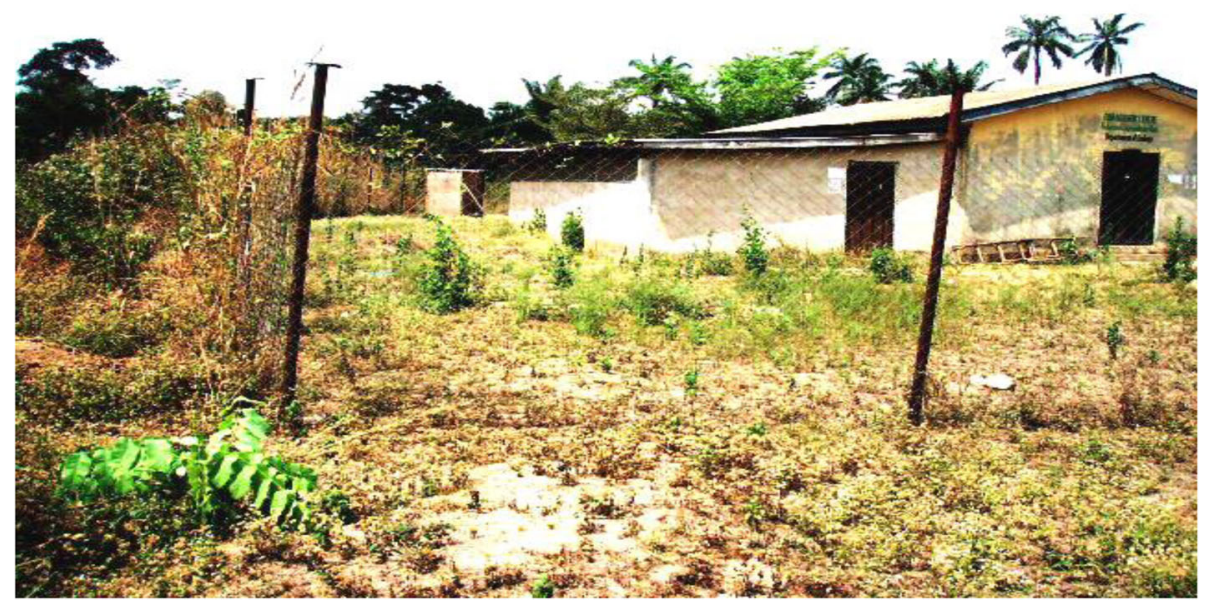

Fig. 3 Overview of the animal house, Department of Zoology Annex, where the simulated building was erected for the study

maggots from each of the batches were reared to adults to estimate the time taken for them to emerge into adults counting from the day the pig cadavers were sacrificed and deposited in the building. The maggots were fed with fresh pork bought from the market the same day the pigs were sacrificed. The pork was kept in a container and covered with a muslin cloth and held in place with a rubber band to exclude flies from accessing it. The pork was not preserved in any form. This is to have a feeding source similar in decomposition status of the pig cadavers where the maggots were collected. Both the adult flies collected with a sweep net and the emerged flies reared in the laboratory were compared and identified with reference to insects of Nigeria checklist and bibliography (Medler 1980). The identified flies were verified by a taxonomist at the Institute of Agricultural Research, Ahmadu Bello University Zaria, Nigeria.

The remaining samples of the maggots collected between day 4 and day 20 representing the three batches were killed with hot water and preserved with $70 \%$ ethanol. One gram of each of the preserved maggots for each day which were morphologically dissimilar and representing three dipteran maggot families was washed with distilled water. The washed maggots were digested with $10 \mathrm{ml}$ of $70 \%$ chloric acid $\left(\mathrm{HOCl}_{4}\right)$ and $10 \mathrm{ml}$ of concentrated nitric acid $\left(\mathrm{HNO}_{3}\right)$ by indirectly heating with a water bath at $60^{\circ} \mathrm{C}$ for $1 \mathrm{~h}$ in a fume cupboard. The filtered solution of the digested maggots was analyzed with an atomic absorption spectrophotometer (AAS-model: BUCK Scientific 210GP) to assess and quantify zinc and phosphorus contained in the maggots collected during the rainy season. This process was repeated for the dry season study. However, the collected adult and emerged flies in the study were not assessed for zinc and phosphorus due to some constraints.
The time taken for the cadavers to decompose, the ambient temperature, and the relative humidity during the rainy and the dry seasons of the study were statistically analyzed with Student's $t$ test at 95\% significant level to compare their mean difference.

\section{Results}

The pig cadavers completely skeletonized between 10 and 16 days during the rainy and dry seasons respectively, irrespective of the killing methods. Four decomposition stages, fresh, bloated, wet decay, and skeletonized remains, were observed at various durations during the rainy season while five decomposition stages, fresh, bloated, wet decay, dry decay, and skeletonized remains, were observed at various durations during the dry season. The difference between the time taken for the pig cadavers to completely decompose between the two seasons was significant (Fig. 4). The mean temperature and the relative humidity recorded in the building during the rainy season were $28.1{ }^{\circ} \mathrm{C}$ and $80 \%$ respectively. During the dry season, temperature and relative humidity recorded were $34.7^{\circ} \mathrm{C}$ and $29 \%$ respectively. There was significant difference $(P<0.05)$ between the temperature and the relative humidity of the rainy season and the dry season (Fig. 4). In the morning of day 4 counting from the day of deposition of the cadavers during the rainy season, the third instars of maggots collected as the first batch of maggots while feeding on the poisoned and the strangled cadavers began to emerge on day 8. Eightyfive percent $(85 \%)$ of them reared in the laboratory emerged as adult blow flies on day 8 while the remaining $15 \%$ of them emerged on day 9 . The days at which these maggots from the first batch emerged also synchronized with the days at which similar maggots within the pig cadavers were seen emerging in the building irrespective of the cadavers (poisoned or strangled) they fed on. Thus, a surge of newly emerged blow flies was observed in the building. These 


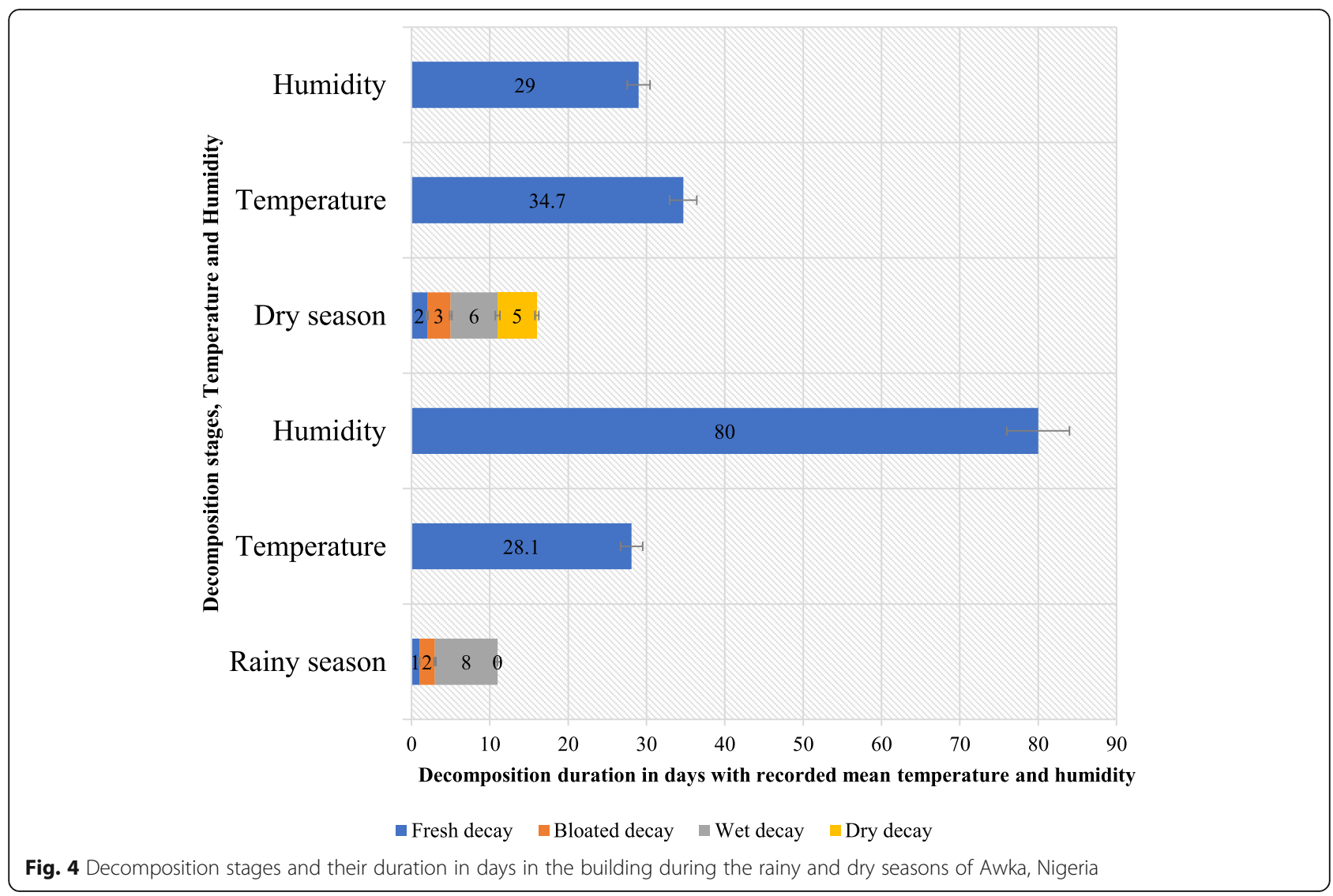

blow flies include Chrysomya albiceps (Weid.), Chrysomya chloropyga (Weid.), and Chrysomya regalis (Rob-Desv.) in the family Calliphoridae.

The fly that emerged from the second batch of the maggots was ulidiid fly (Chrysomyza africana (Hendel) in the family Ulidiidae. About $90 \%$ of the ulidiid fly emerged on day 22; no further emergent was observed till end of the study. In the third batch, the fly that emerged was black soldier flies Hermetia illucens (Linn.) in the family Stratiomyidae. Only $70 \%$ of the black soldier fly successfully emerged on day 33 . Another 5\% emergent was observed on day 41 but was not counted because only the head capsule was seen while the remaining body parts were tucked in the pupal casing for some hours and later died. During the dry season, all the 20 maggots $(100 \%)$ of the first and second batches emerged successfully on day 9 and day 22 respectively while $85 \%$ of the maggots from the third batch emerged on day 33 , and the remaining $15 \%$ emerged on day 34 . Based on the laboratory rearing of the maggots, there was no emergent difference observed between the maggots collected from the poisoned and strangled pig cadavers.

The quantity of zinc and phosphorus detected on the maggots' tissues with AAS is shown in Figs. 5 and 6. The AAS detected and quantified zinc in all the maggot samples from the poisoned cadavers but did not detect phosphorus. The maggot samples collected from the strangled cadavers did not show presence of zinc or phosphorus.

\section{Discussion}

Dipteran maggots are allogenics based on their behavioral adaptability. Hence, they usually take residence on vertebrate cadavers especially when the cadaver is accessible by adult flies. They are known to consume cadaver tissues of all sources, but consuming poisoned cadavers was expected to affect their development. In this study, the zinc phosphide poison was hypothetically expected to affect the cadaver decomposition but was not observed as decomposition commenced immediately after death and as well attracted insects mainly dipteran flies few hours after death. The only difference observed in the decomposition duration of the cadavers was as a result of seasonal changes that influenced the temperature and the relative humidity of the two seasons and not as a result of the poison. This is contrary to the report (Gunatilake and Goff 1989) that malathion in the tissues of a decomposing body delayed insects' colonization and oviposition for several days. This was contained in a study of a suicide case where malathion pesticide had been consumed. The developmental stages of blow flies found on the dead body indicated a minimum postmortem interval of 5 days while the victim was last seen alive 8 days prior to the discovery of the body. 


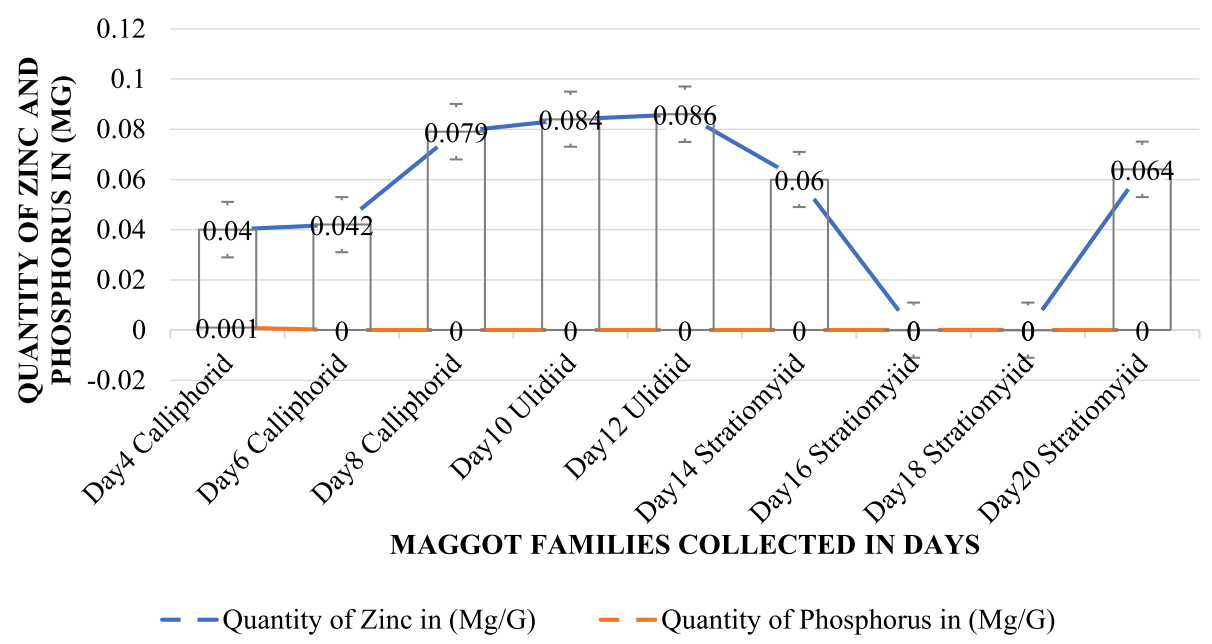

Fig. 5 Quantity of zinc and phosphorus in the maggots during the rainy season at Awka, Nigeria

Insect composition of the pig cadavers was continuously the same irrespective of what killed the pigs. Hence, the maggots from the three dipteran fly families (Calliphoridae, Ulidiidae, and Stratiomyidae) were unique and consistent on the cadavers irrespective of the difference in temperature and relative humidity that existed between the rainy and the dry seasons. The eclosion and adult emergent of the dipteran flies collected from the poisoned and the strangled pigs and reared in the laboratory were not altered. Thus, the flies that emerged from the maggots reared in the laboratory were among the flies reported in Okija, Nigeria, (Abajue et al. 2014) as insects of forensic importance. In Nigeria, a report (Ewuim and Abajue 2016) has it that these flies were among the common flies that were continually collected and documented so far as forensic insects associated with decomposing pig carrions in Nigeria. Therefore, the unavoidable infestation of the pig cadavers by these flies with their maggots via their laid eggs in an indoor scene and on poisoned cadavers, present them as useful samples for toxicological analysis in forensic toxicology of a badly decomposed corpse suspected to die of a toxic substance.

The components of the poison especially zinc were assumed to accumulate in the cadaver tissues and were stored in the cuticles of the maggots that fed on the poisoned pig cadavers, thus, supporting the reports (Amendt et al. 2004) that larvae feeding on a corpse may accumulate drugs and toxicants which had been ingested by the dead person. It is therefore interesting to note that if a toxic substance is ingested by a deceased person, the probability is that dipteran maggots found on the body will accumulate the substance. This may be

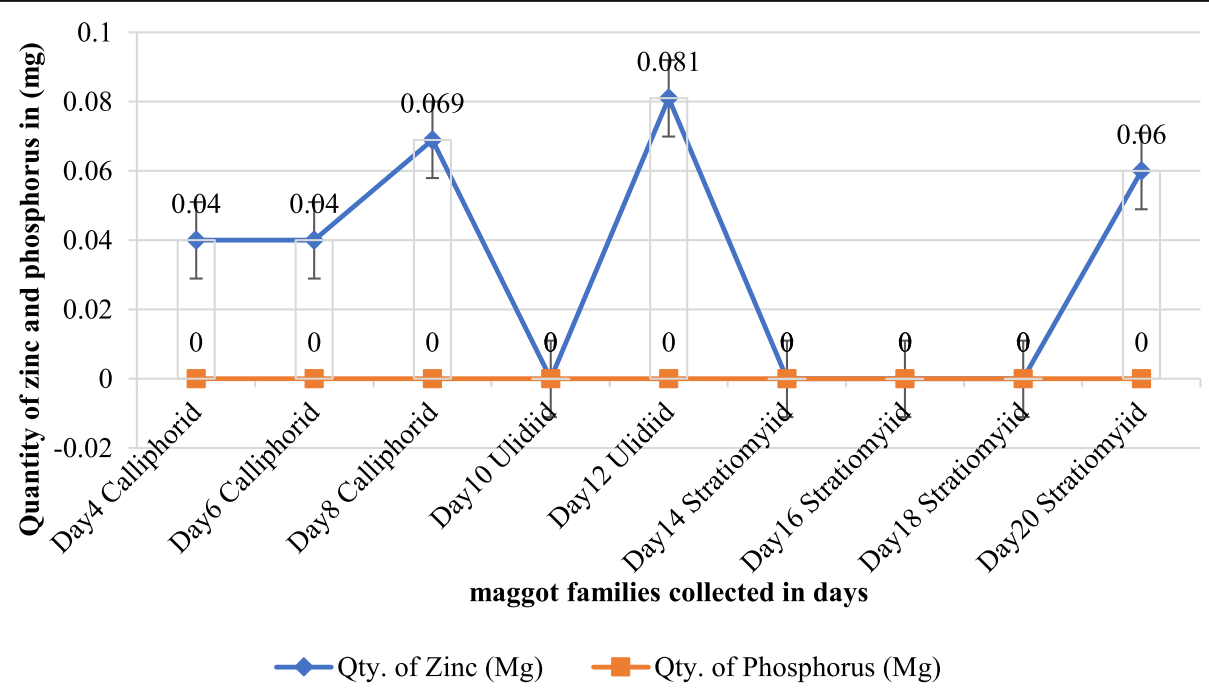

Fig. 6 Quantity of zinc and phosphorus in the maggots during the dry season of Awka, Nigeria 
necessary when maggot samples collected on the body is glaring that the victim was suspected to die of suspected toxic substance. That the zinc component of the zinc phosphide usually sold without control in Awka as rat killer, which killed the pigs and was assessed in the fly maggots, is thus an evidence base report that the substance is toxic and capable of killing human being. The detection of poisonous metals such as mercury in the larvae of various species of blowflies reared on tissues containing known concentrations of mercury has been reported (Nuorteva and Nuorteva 1982). Toxicological data from fly larvae was reported to be reliable as well as those from cadaver tissues (Kintz et al. 1990). A study of Nolte et al. (Nolte et al. 1992) reported that cocaine and its breakdown products have been found in small quantity in the puparium of a calliphorid fly, thus, validating the present report which assessed zinc in the maggots that fed on zinc phosphide-poisoned pig cadavers.

It is interesting to note that metabolisms of pesticides are usually rapid, hence, the zinc phosphide rapidly metabolized in the cadaver body, thus, liberating the phosphorus into phosphine gas which caused acute kidney, lung, and heart failures. This biochemistry might be the reason the phosphorus component was not detected. Therefore, this metabolic pathway may be the reason why the zinc component of the poison was assimilated in the maggots irrespective of the climatic difference between the two seasons. Zinc is a heavy metal nutritionally essential in small quantity. However, directly or indirectly consuming it in large amount will cause acute or chronic toxicity or poisoning of vital organs in the body. Consumption of heavy metals such as zinc becomes toxic when they are not metabolized by the body and accumulate in the soft tissues of the body (Ezeonu 2015). The acute toxicity of the zinc phosphide caused the death of the pigs, but the non-metabolism of the zinc component in the pig tissues may have led to its recovery on the fly maggots that fed on the poisoned cadavers.

\section{Conclusion}

Based on the findings in this study, the elapsed time between the decomposition of the poisoned and the strangled pigs in the simulated building was the same irrespective of the seasons of the study. Fly maggots collected on the poisoned and strangled cadavers also emerged as adults at the same time. The presence of zinc phosphide in the pig cadavers did not delay or speed up the cadaver's decomposition and neither did it alter the maggots' development nor the emergent of the adult flies. Therefore, we suggest that maggot samples found on a decomposing cadaver suspected to die of poison should be assessed for components of suspected poisons especially when the cadaveric fluids and tissues have dried up.

\section{Abbreviations}

AAS: Atomic absorption spectrophotometer; Fig: Figure; Figs: Figures

\section{Acknowledgements}

Not applicable

\section{Authors' contributions}

MCA deposited the sacrificed pig cadavers in the building, monitored and recorded the cadaver's decomposition as well as collected and processed all the insects on the cadavers for further analysis and evaluation. SCE instructed and supervised all the activities carried out by MCA and edited the manuscripts that followed thereafter. The authors declared that there is no conflict of interests. The authors read and approved the final manuscript.

\section{Funding}

Not applicable

\section{Availability of data and materials}

Not applicable

\section{Ethics approval and consent to participate}

At the time of the study, there was no ethical committee in relation to animal use in research in the university. However, all the principles of the 3Rs of the guidance on the operations of the 2014 revised Animal (Scientific Procedures) Act 1986 were observed.

Consent for publication

Not applicable

\section{Competing interests}

The authors declared that they have no competing interest.

\section{Author details}

${ }^{1}$ Department of Animal and Environmental Biology, University of Port Harcourt, Port Harcourt, Nigeria. ${ }^{2}$ Department of Zoology, Nnamdi Azikiwe University, Awka, Nigeria.

Received: 26 March 2020 Accepted: 27 September 2020

Published online: 03 October 2020

\section{References}

Abajue MC, Ewuim SC, Akunne CE (2014) Preliminary checklist of flies associated with pig carrions decomposition in Okija, Anambra State, Nigeria. An Res Int 11(1):1899-1904

Amendt J, Krettek R, Zehner R (2004) Forensic entomology. Naturwissenschaften 91:51-65

Benecke M (2001) A brief history of forensic entomology. Forensic Sci Int 120(12):2-14

Bourel B, Fleurisse L, Hedouin V, Cailliez JC, Creusy C, Gosset D, Goff ML (2001) Immunohistochemical attribution to the study of morphine metabolism in Calliphoridae larvae and implications in forensic entomotoxicology. J Forensic Sci 46:596-599

Campobasso CP, Gherardi M, Caligara M, Sironi L, Introna F (2004) Drug analysis in blowfly larvae and in human tissues: a comparative study. Int J Legal Med 118:210-214

Enete IC, Ikepeazue FO, Ugwu J (2014) Aspects of rainfall characteristics in Awka centre. J Agric Environ Sci 3(2):117-127

Ewuim SC, Abajue MC (2016) Forensic entomology: the journey so far in Nigeria. Open Sci J Biosci Bioeng 3(1):1-4

Ezeonu FC (2015) Poisons in the Nigeria environment: within our reach, beyond our control. 25th Inaugural Lecture, Nnamdi Azikiwe University, Nigeria. Rex Charles and Patrick limited, Nimo, Anambra State, 92 pp.

Gagliano-Candela R, Aventaggiato L (2001) The detection of toxic substances in entomological specimens. Int J Legal Med 114:197-203

Gennard DE (2007) Forensic entomology: an introduction. Wiley, New York

Goff ML, Lord WD (1994) Entomotoxicology: a new area of forensic investigation. Am J Forensic Med Pathol 15:51-57

Greenberg B, Kunich JC (2002) Entomology and the law: flies as forensic indicators. Cambridge University Press, Cambridge

Gunatilake K, Goff ML (1989) Detection of organophosphate poisoning in a putrefying body by analyzing arthropod larvae. J Forensic Sci 34:714-716 
Hobischak NR, Anderson GS (2002) Time of submergence using aquatic invertebrate succession and decompositional changes. J Forensic Sci 47:142-151

Introna F, Campobasso CP, Goff ML (2001) Entomotoxicology. Forensic Sci Int 120:42-47

Introna F, Lo Dico C, Coplan YH, Smialek JE (1990) Opiate analysis in cadaveric blowfly larvae as an indicator of narcotic intoxication. J Forensic Sci 35:118-122

Keiper JB, Casamatta DA (2001) Benthic organisms as forensic indicators. J N Am Benthol Soc 20(2):311-324

Kintz P, Tracqui A, Mangin P (1990) Toxicology and fly larvae on a putrefied cadaver. J Forensic Sci Society 30:243-246

Medler J (1980) Insects of Nigeria-checklist and bibliography. Memoirs Am Entomological Institute 30:1-919

Miller ML, Lord WD, Goff ML, Donnelly D, McDonough ET, Alexis JC (1994) Isolation of amitriptyline and nortriptyline from fly pupariae (Phoridae) and beetle exuviae (Dermestidae) associated with mummified human remains. $J$ Forensic Sci 39:1305-1313

Nolte KB, Pinder RD, Lord WD (1992) Insect larvae used to detect cocaine poisoning in a decomposed body. J Forensic Sci 37:1179-1185

Nuorteva P, Nuorteva SL (1982) The fate of mercury in sarcosaprophagous flies and in insects eating them. Ambio 11:34-37

Smith KGV (1986) A manual of forensic entomology. Trustees of the British Museum (Natural History) and Cornell University Press, London

Tomberlin JK, Byrd JH, Wallace JR, Benbow ME (2012) Assessment of decomposition studies indicates need for standardization and repeatable research methods in forensic entomology. J Forensic Res 3(5):1-10

\section{Publisher's Note}

Springer Nature remains neutral with regard to jurisdictional claims in published maps and institutional affiliations.

\section{Submit your manuscript to a SpringerOpen ${ }^{\circ}$ journal and benefit from:}

- Convenient online submission

- Rigorous peer review

- Open access: articles freely available online

High visibility within the field

- Retaining the copyright to your article

Submit your next manuscript at $\boldsymbol{\nabla}$ springeropen.com 